\title{
TITLE:
}

\section{FLESHY ALCYONARIANS FROM SOUTHERN FORMOSA}

\author{
$\operatorname{AUTHOR}(S)$ :
}

Utinomi, Huzio

\section{CITATION:}

Utinomi, Huzio. FLESHY ALCYONARIANS FROM SOUTHERN FORMOSA. PUBLICATIONS OF THE SETO MARINE BIOLOGICAL LABORATORY 1959, 7(3): 303-312

\section{ISSUE DATE:}

1959-12-20

URL:

http://hdl.handle.net/2433/174638

RIGHT: 


\title{
FLESHY ALCYONARIANS FROM SOUTHERN FORMOSA ${ }^{13}$
}

\author{
HuZIO UTINOMI \\ Seto Marine Biological Laboratory, Sirahama
}

With 4 Text-figures

For a month from May to July, 1938, about twenty years ago, I made a collecting trip to Formosa (Taiwan) for investigating the coral reefs and littoral fauna, especially to collect the cirripeds and alcyonarians. A general sketch of the coastal fauna of southern Formosa was already given in HIRO (1939a), and the systematic and ecological accounts of the cirripeds were also given in HIRO (1939b).

In this paper is given only a systematic list of the fleshy alcyonarians collected mainly on the southern coasts of Formosa between 7th and 16th of June, 1938. Among them, some of the most interesting forms were described in detail in three former papers (UTINOMI, 1950a, 1950b and 1951).

This study was supported by a grant-in-aid from the Japan Society for the Promotion of Scientific Research. I am indebted to Dr. Katura Oyama for information on the homonymies of Sphaerella.

\section{List of the Alcyonarian Collection from Formosa}

\section{STOLONIFERA}

\section{Family Clavulariidae HrCKsoN}

\section{Clavularia racemosa UTinom, 1950}

Occurrence: Kizan near Suô, northeastern coast of Formosa. June 29, 1938.

Found on the root of a green alga Caulerpa racemosa var. clavifera WEBER VAN Bosse (UTiNomi, 1950b, p. 44).

Previously recorded also from southern Japan (type locality-Tanabe Bay, Kii Province) (Utinomi, 1950b).

\section{Clavularia inflata SCHENK, 1896}

Occurrence: Daizyubô, southern end of Formosa. June 14, 1938.

1) Contributions from the Seto Marine Biological Laboratory, No. 336.

Publ. Seto Mar. Biol. Lab., VII (3), 1959. (Article 18) 
Luxuriant on dead coral blocks and rock in shallow tide-pools. In life, the rigid anthosteles, about $25-30 \mathrm{~mm}$ long, are brownish yellow and the fully expanded anthocodiae pale brownish in color.

Previously recorded from Great Barrier Reef (MACFADYEN, 1936), East Indies (Schenk, 1896; Thomson and Dean, 1931 as Hicksonia köllikeri Dean), Philippines (MAY, 1900 ; ROXAS, 1933a, as Clavularia inflata var. luzoniana MAY), Tokara Islands (Utrinomi, 1953) and Ponape Island, Caroline group (Utinomi, 1956).

\section{Pachyclavularia violacea (QUOY \& GAIMARD, 1833)}

Occurrence: Daizyubô, southern end of Formosa. June 14, 1938.

Luxuriant in shallow tide-pools. The colonies of extraordinary appearance are bright reddish purple in colour. In life, the color of the anthocodiae fully extended is ocher red, though pale cinnamon pink around the central mouth. The neck portion below the tentacles extended out of the red anthostelar portion is only brownish.

Previously recorded from Vanikoro, Santa Cruz Islands (type locality) (Quoy \& GAIMARD, 1833 as Clavularia violacea), East Indies (ROule, 1908; ThOMson \& DeAN, 1931, as Pachyclavularia erecta Roule), Philippines (RoXAs, 1933 a, as P. erecta), Great Barrier Reef (MAcFadyen, 1936, as P. erecta) and Titizima, Bonin Islands (UTinomi, 1956). For synonymies see Gohar, 1940.

\section{Family Tubiporidae GrAY}

\section{Tubipora musica Linnaeus, $\mathbf{1 7 5 8}$}

Occurrence: Garanbi, southernmost cape of Formosa. June 13, 1938.

Overgrown on coral shingles in tide-pools. This well-known "organ-pipe coral" is very common around the frinzing reefs of southern Formosa, but the color of living polyps when expanded may mislead its occurrence there, since the tentacles are apparently either pale cinnamon pink, olive yellow or glaucous green and the polyp stalk brown uniformly (according to my field note).

Widespread in all tropical Indo-Pacific Ocean from Red Sea to Australia.

\section{ALCYONACEA}

\section{Family Xeniidae VERRILL}

\section{Anthelia formosana UTINOMI, 1950}

Occurrence: Garanbi, southernmost cape of Formosa. June 13, 1938.

Luxuriant in tide-pools under the light house. When alive, they are uniformly bluish white, basal membrane spreading over sponges or other solid substratum with numerous, non-pulsating, polyps close together (UTINOMI, 1950a, p. 82). 


\section{Heteroxenia elisabethae KöLLIKER, 1875}

Occurrence: Garanbi, southernmost cape of Formosa. June 13, 1938.

Abundant in tide-pools south and west of the light house (UTINOMI, 1950a, p. 85).

Previously recorded from East African coast, Great Barrier Reef, East Indies, Philippines (HICKSON, 1931; Roxas, 1933a).

\section{Cespitularia stolonifera GOHAR, 1938}

Occurrence: Garanbi, southernmost cape of Formosa. June 12, 1938.

A large branched colony was found in a tide-pool south of the light house. Caphyra- or Lissocarcinus-like small crabs were found commensally between polyps (UTiNomi, 1950a, p. 90).

Previously recorded from Amboina by Wright \& Studer (1889) as Xenia elongata DANA (cf. GoHAR, 1938, p. 483).

\section{Family Asterospiculariidae UTINom \\ 8. Asterospicularia laurae UTiNom, 1951}

Occurrence: Daizyubô. June 14, 1938.

This unique alcyonarian with stellate spicules alone is seemingly a branched colony with a few mushroom-like lappets covered by a number of monomorphic polyps lacking pinnules on tentacles (UTINOMI, 1951).

\section{Family Alcyoniidae LAMOUROUX}

\section{Sinularia polydactyla (EHRENBERG, 1834)}

(Fig. 1, $a-b$ )

Occurrence: Ryûkyûsyo (Lambay Island). June 8, 1938.

Growing to large size, brown or gray in color, with stout laterally flattened lobes. Widely distributed in Indo-Westpacific tropical shallow waters.

\section{Sinularia mayi LÜTTSCHWAGER, 1915}

(Fig. 1, $c-e$ )

Occurence: Daizyubô. June 14, 1938.

Abundant on reef edges. Colonies rather low (about $7 \mathrm{~cm}$ high in alcohol specimens), grayish white in color. In one colony a gastropod Rapa rapa (LinNaeus) was found as embedded wholly in the bark of the stalk. 
Previously recorded from East Indies, Philippines (LütTschwager, 1915 ; Roxas, 1933b) and Indochina (TIXIER-Durivault, 1945).
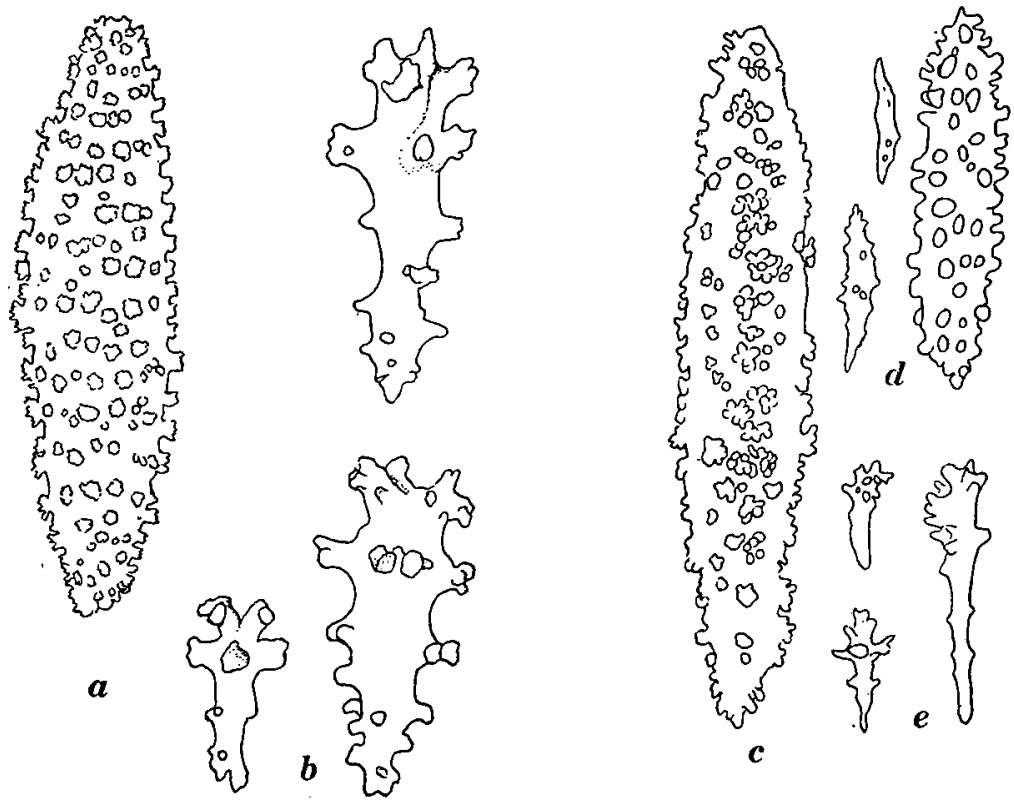

Fig. 1. $a-b$. Sinularia polydactyla (EHRENBerG). $a$, coenenchymal spicule; $b$, cortical spicules. $c-e$. Sinularia mayi LÜTTSCHWAGER.

$c, d$, coenenchymal spicules; $e$, cortical spicules. $(a, c, d \times 18 ; b \times 150 ; e \times 75)$

\section{Sarcophyton ehrenbergi MARENZELLER, 1886}

Occurrence: Daizyubô. June 14, 1938.

One colony with feebly folded cup-shaped disc, about $6 \mathrm{~cm}$ across, was collected. Widely distributed in tropical Indo-Westpacific waters (TIXIER-DurivaulT, 1958).

12. Sarcophyton acutangulum (MARENZELLER, 1886)

Occurrence: Daizyubô. June 14, 1938.

One colony with the disc, $3.5 \mathrm{~cm} \times 5.4 \mathrm{~cm}$ in size, strongly folded into high folds slightly projecting from the stalk, was collected. Autozooids in the center of the disc are as usual raised as mounds and about $3 \mathrm{~mm}$ apart.

Widespread in tropical Indo-Westpacific, as far north as Kii coast of southern Japan (UTINOMI, 1954a, 1956). 


\section{Sarcophyton moseri RoxAS, 1932}

Occurrence: Daizyubô. June 14, 1938.

One small colony with $3 \mathrm{~cm}$ high stalk and unfolded disc, about $2.2 \mathrm{~cm} \times 3.2 \mathrm{~cm}$ in size, was collected.

Previously recorded from Philippines (Roxas, 1932, 1933b), New Caledonia (TIXIER-Durivault, 1946, 1958) and Tokara Islands, southern Japan (UTinomi, 1953).

\section{Sarcophyton glaucum (QUOY \& GAIMARD, 1833)}

(Fig. 2)

Occurrence: Daizyubô. June 14, 1938.

Ryûkyûsyo. June 7, 1938.

Common in shallow waters near reef edges.

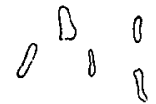

$\boldsymbol{a}$

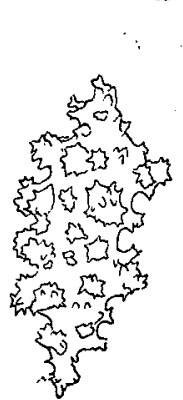

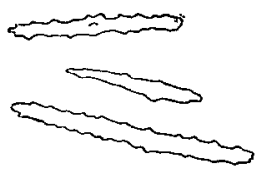

b

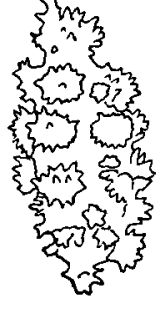

c

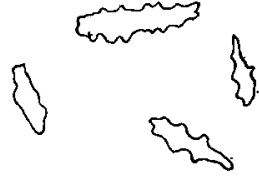

$\boldsymbol{d}$

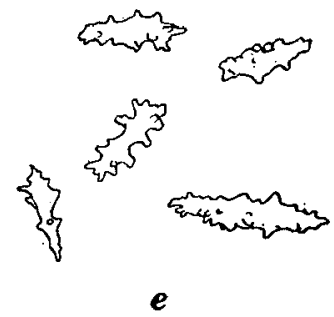

Fig. 2. Sarcophyton glaucum (QUOY \& GAIMARD).

$a$, tentacle spicules; $b$, coenenchymal spicules of capitular disc; $c$, coenenchymal spicules of stalk; $d$, cortical spicules of capitular disc; $e$, cortical spicules of stalk. (All $\times 100)$

Largest one among many specimens brought home measures about $10 \mathrm{~cm}$ across and $5 \mathrm{~cm}$ high in alcohol.

Widespread in tropical Indo-Westpacific (MOSER, 1919, p. 253 ; TiXIER-Durivault, 1958). Not ever found in Japan proper.

15. Sarcophyton tropheliophorum (MARENZELLER, 1886)

Occurrence: Daizyubô. June 14, 1938. 
Common on reef edges. In one specimen collected there, the disc is $3 \mathrm{~cm} \times 4 \mathrm{~cm}$ in size and strongly convoluted at margins into 8 thick main folds.

Widespread in the Indo-Westpacific, as far north as Tokara Islands (UTINOMI, 1953, p. 231 ; Tixier-Durivault, 1958).

\section{Cladiella sphaerophora (EHRENBERG, 1834)}

(Fig. 3)

Occurrence: Daizyubô. June 14, 1938.

Two small cerebriform grayish white colonies were collected. One of them figured here is $29 \mathrm{~mm} \times 33 \mathrm{~mm}$ in size and $15 \mathrm{~mm}$ in height. Its basal attachment is $15 \mathrm{~mm} \times 20 \mathrm{~mm}$ and flattened.

Polyps are very minute, thickly set on roundly constricted lobes, and they are about $0.5-0.7 \mathrm{~mm}$ apart. Cortical spicules are tuberculate capstans with distinct
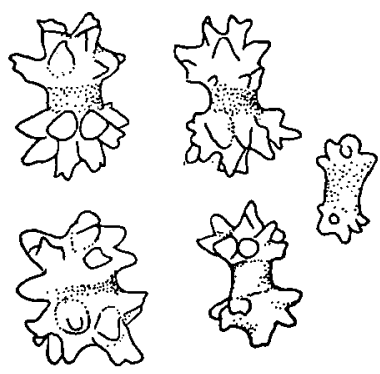

$\boldsymbol{b}$

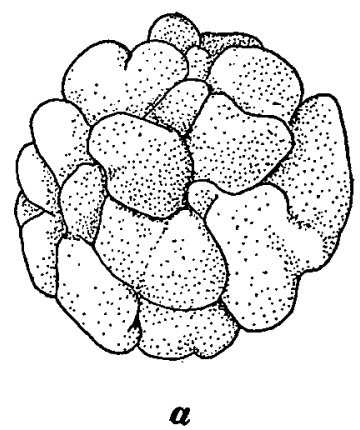

$\boldsymbol{a}$

Fig. 3. Cladiella sphaerophora (EHRENBERG).

$a$, compressed colony, upper view ; $b$, cortical spicules of lobes. $(a \times 1 ; b \times 150)$

median waist and covered by many rounded tubercles. They are about $0.07-0.09 \mathrm{~mm}$ long and $0.04-0.05 \mathrm{~mm}$ wide. Besides, smaller discs, about $0.02 \mathrm{~mm} \times 0.04 \mathrm{~mm}$, are found.

Previously recorded from Red Sea (Ehrenberg, 1834 ; Klunzinger, 1877 ; TixierDurivault, 1948), Madagascar, Seychelles, East African coast, Tahiti, East Indies and Bonin Islands (UTinomi, 1956).

\section{Cladiella pachyclados (KLUNZINGER, 1877)}

Occurrence: Daizyubô. June 14, 1938 .

Common on reef edges. Colonies grayish in color, with low finger-like lobes not so much compressed as in C. sphaerophora. 
Widespread in Indo-Westpacific tropical waters (KIUNZINGER, 1877 ; MACFADYEN, 1936 ; TIXIER-Durivault, 1948).

\section{Family Nephtheidae VERRILL}

\section{Paralemnalia thyrsoides (EHRENBERG, 1834)}

Occurrence: Garanbi. June 12, 1938.

Two fine colonies, brownish in life, with retractile polyps all over the finger-like lobes up to $6 \mathrm{~cm}$ long, were collected.

Previously recorded from Red Sea, Indian Ocean, East Indies, Philippines, Great Barrier Reef and Palau Islands (Utinomi, 1956).

\section{Nephthea erecta KÜKENTHAL, 1903}

Occurrence: Daizyubô. June 14, 1938.

Previously recorded from Tonga Islands, East Indies, Philippines and Kii coast, southern Japan (UTINOMI, 1954b).

\section{COENOTHECALIA}

\section{Family Helioporidae MOSELEX}

20. Heliopora coerulea (PALLAS, 1766)

Occurrence: Daizyubô. June 14, 1938.

Only a dead fragment of the colony was obtained.

Widespread in tropical Indo-Westpacific, as far north as Tokara Islands, southern Japan (UTINOMI, 1953, 1956).

\section{GORGONACEA}

\section{SCLERAXONIA}

\section{Family Briareidae GRAY}

\section{Solenopodium marquesarum (KÜKENTHAL, 1916)}

(Fig. 4)

Occurrence: Daizyubô. June 14, 1938.

A hump-shaped colony with a hollow center was collected. It is about $3 \mathrm{~cm}$ long and $3.5 \mathrm{~cm}$ wide. The outer surface is dull grayish brown, while the inner surface is beautifully violet. The outer cortical spicules are all colorless tuberculate spindles, while those of the inner medulla are violet-colored, more slender spindles or irregularly branched forms. 
This species was originally assigned to the genus Erythropodium (KüKENTHAL, 1916, 1919 and 1924), but later transferred to the genus Solenopodium by MolandER (1929, p. 39), Aurivillius (1931, p. 9), Macfadyen (1936, p. 67) and Stiasny (1937,

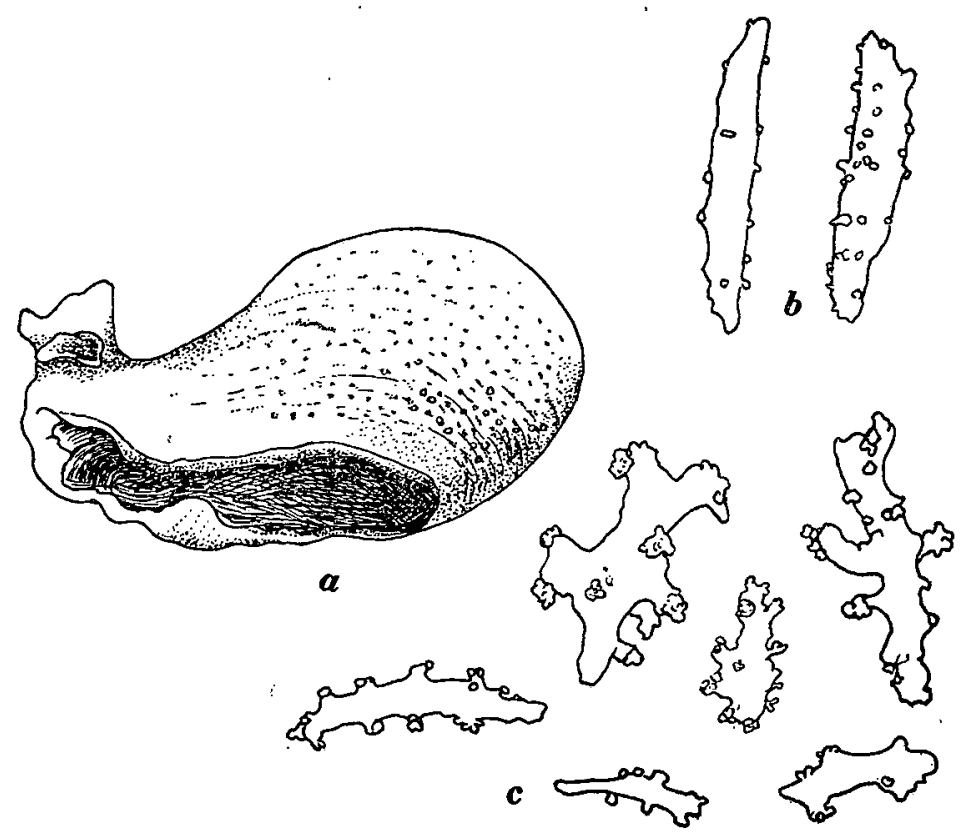

Fig. 4. Solenopodium marquesarum (KüKENTHAL).

$a$, hump-shaped colony ; $b$, cortical spicules of outer layer, colorless;

$c$, cortical spicules of inner layer, violet colored. $(a \times 1 ; b, c \times 60)$

p. 15), though the former three authors consider as an encrusting form of the more branched cylindrical species $S$. stechei (KüKENTHAL).

Previously recorded from Marquesas Islands, Timor and Low Isles (StIAsny, 1937, pp. 9-19).

\section{Proposal of using Gray's Cladiella instead of his Sphaerella}

For the Indo-Pacific encrusting alcyoniids having exclusively very small capstanformed spicules and minute finger-biscuit-like discs in the coenenchymes BAYER (1955, p. 207) proposed to adopt the oldest genus name Sphaerella (GRAY, 1869, p. 122 ; genotype-Alcyonium tuberculosum QUOY \& GAIMARD), because the name was earlier erected than Microspicularia MACFADYEN (1936, p. 28; genotype-Alcyonium pachyclados KLunzinger). Tixier-Durivault (1957) also revived that name. 
Regret to say, however, this genus name is preoccupied by Sphaerella SommerFELT 1824 (= Haematococcus AGARDH) of the Flagellata (Protozoa) and also by Sphaerella CONRAD 1838 and 1860 of the fossil Lamellibranchia (Mollusca), as pointed out by NeAve (1940, vol. IV, p. 238 and Cherbonnier, 1958). Another genus name Cladiella erected by GRAY (1869, p. 125) is thus a subjective junior synonym of Sphaerella GRAY.

GRAY erected Cladiella for two species Lobularia sphaerophora EHRENBERG 1834 and Alcyoninm brachycladium DANA 1846 (=Lobularia brachyclados EHRENBERG 1834), but failed to indicate a type species. Therefore, I hereby propose to revive this Cladiella as the next available genus name and to designate $L$. spherophora Ehrenberg as the type of Cladiella. For this genus MaCfadyen's definition of the genus Microspicularia (1936, p. 29) is wholly applicable.

\section{LITERATURE CITED}

AURIvillius, M. 1931. The gorgonarians from Dr. Sixten Bock's Expedition to Japan and Bonin Islands 1914. Kungl. Sv. Vetenskapsakad. Handl., Ser. 3, vol. 9, no. 4, pp. 1-337, 6 pls.

BAYER, F. M. 1955. Contributions to the nomenclature, systematics, and morphology of the Octocorallia. Proc. U.S. Natl. Mus., vol. 105, pp. 207-220, 8 pls.

BURCHARDT, E. 1902. Alcyonaceen von Thursday Island (Torresstrasse) und von Amboina. II. Alcyonaceen von Amboina. Denkschr. Med.-nat. Ges. Jena, vol. 8, pp. 653-682, pls. 54-57.

Cherbonnier, G. 1958. Sur le genre Globosita n. n.= Sphaerella Heding et Panning (Holothuries dendrochirotes). Bull. Mus. Nat. Hist. Nat. Paris, Ser. 2, vol. 30, no. 2, p. 198.

*DANA, J. D. 1846. Report on Zoöphytes of the U.S. Exploring Expedition under Captain C. Wilkes, 1838-1842. Philadelphia.

EhrenberG, C. G. 1834. Die Corallthiere des Roten Meeres. Berlin.

Gohar, H. A. 1938. On a new species of Cespitularia and two invalid species of Xenia and Clavularia. Proc. Zool. Soc. Lond., B, vol. 108, pt. 3, pp. 483-487, pl. 1.

1940. A revision of some genera of the Stolonifera. Publ. Mar. Biol. St. Ghardaqa (Red Sea), no. 3, pp. 3-32, pl. 1.

GRAY, J. E. 1869 . Notes on the fleshy alcyonoid corals (Alcyonium, Linn., or Zoophytaria Carnosa). Ann. Mag. Nat. Hist., Ser. 4, vol. 3, pp. 117-131.

Hickson, S. J. 1931. The alcyonarian family Xeniidae, with a revision of the genera and species. Great Barr. Reef Exped., Sci. Rep., vol. 4, no. 5, pp. 137-179, 2 pls.

Hiro, F. (=TINomi, H.) 1939a. A glimpse on the coral reef and coastal fauna of southern Formosa. Bot. \& Zool., vol. 7, pp. 889-1062. (In Japanese)

1939b. Studies on the Cirripedian fauna of Japan. IV. Cirripeds of Formosa (Taiwan), with some geographical and ecological remarks on the littoral forms. Mem. Coll. Sci., Kyoto Imp. Univ., Ser. B, vol. 15, no. 2, pp. 245-284.

KLUNZINGER, C. B. 1877. Korallthiere des Rothen Meeres. Erster Theil: Die Alcyonarien und Malacodermen. Berlin. 94 pp., 7 pls.

KölıIKer, A. 1875. Die pennatulide Umbellula und zwei neue Typen der Alcyonarien. Festschr. phys.-med. Ges. in Würzburg, pp. 1-23, 1 pl.

KÜkenthal, W. 1903. Versuch einer Revision der Alcyonarien. II. Die Familie der Nephthyiden. 1 Theil. Zool. Jahrb. Abt. Syst., vol. 19, pp. 99-172, pls. 7-9. 444-484.

1916. Die Gorgonarien Westindiens. Kap. 1. Scleraxonier. Zool. Jahrb. Suppl., 11, pp. 1919. Gorgonaria. Wiss. Ergebn. Valdivia-Expedition, vol. 13, Teil 2, Ht. 1-2, pp. 1946. Jena. 
Kükenthal, W. 1924. Gorgonaria. Das Thierreich 47. xxviii+478 pp. Berlin and Leipzig.

LüTTSCHWAGER, H. 1915. Beiträge zur einer Revision der Familie Alcyoniidae. Arch. Naturg., 1914, A 10, pp. 1-42.

1922. Alcyonarien von den Philippinen. I. Die Gattung Alcyonium Linnaeus. Philipp. J. Sci., vol. 20, pp. 519-540, 1 pl.

1926. Die Gattung Alcyonium. 2 Teil. Mitt. Zool. Mus. Berlin, vol. 12, pp. 279-289.

Macfadyen, L. M. I. 1936. Alcyonaria (Stolonifera, Alcyonacea, Telestacea and Gorgonacea). Great Barr. Reef Exped., Sci. Rep., vol. 5, no. 2, pp. 19-71, 5 pls.

MARENZEller, E. von 1886. Ueber die Sarcophytum benannten Alcyoniiden. Zool. Jahrb., vol. 1, pp. 341-368, pl. 9.

MAY, W. 1900. Beiträge zur Systematik und Chorologie der Alcyonaceen. Jena. Z. Naturw., vol. 33 , pp. 1-180, pls. 1-5.

Molander, A. R. 1929. Die Octactiniarien. Further Zool. Res. Swedish Antarctic Exped. 1901-03, vol. 2, no. 2, pp. 1-89, pls. 1-5.

Moser, J. 1919. Beiträge zu einer Revision der Alcyonarien. I. Die Gattungen Sarcophyton Lesson und Lobophytum Marenzeller. Mitt. Zool. Mus. Berlin, vol. 9, pp, 219-293, pls. 5-6.

Neave, S. A. 1940. Nomenclator Zoologicus, vol. IV, Q-Z and Supplement, pp. 1-758. London. [p. 238 for Sphaerella]

*QuoY \& GATMARD 1833 . Voyage de l'Astrolabe, Zool., vol. 4. Paris.

Roule, L. 1908. Alcyonaires d'Amboine. Rev. Suisse Zool. Genève, vol. 16, no. 2, pp. 161-194, pls. 6-8.

Roxas, H. A. 1932. Two new species of Sarcophyton Less. from the Philippines. Univ. Philipp. Nat. Appl. Sci. Bull., vol. 4, no. 1, pp. 73-81, pl. 1.

1933a. Philippine Alcyonaria. The families Cornulariidae und Xeniidae. Philipp. J. Sci., vol. 50 , no. 1 , pp. 49-110, pls. 1-4.

1933b. Philippine Alcyonaria, II. The families Alcyoniidae and Nephthyidae. Ibid., vol. 50 , no. 4 , pp. $345-470$, pls. $1-5$.

Schenk, A. 1896. Clavulariiden, Xeniiden und Alcyoniiden von Ternate. Abh. Senckenberg. Naturf. Ges., vol. 23, pp. 41-80, pls. 2-4.

StrasNy, G. 1937. Die Gorgonacea der Siboga-Expedition. Supplement II. Revision der Scleraxonia mit Ausschluss der Melitodidae und Corallidae. Siboga Expeditie, mon. XIIIb ${ }^{8}$, pp. 1-138, pls. 1-8.

Thomson, J. A. \& DeAn, L. M. I. 1941. The Alcyonacea of the Siboga Expedition, with an appendam to the Gorgonacea. Ibid., mon. XIIId, pp. 1-227, 28 pls.

Tixier-Durivault, A. 1946. Les Alcyonaires du Muséum: I. Famille Alcyoniidae. 3. Genre Sarcophytum. Bull. Mus. Nat. Hist. Nat. Paris, Sér. 2, vol. 18, pp. 80-86, 165-191, 348-354.

1948. Révision de la famille des Alcyoniidae. Le genre Lobularia Ehrbg. Mém. Mus. Nat. Hist. Nat. Paris, N. S., vol. 23, no. 1, pp. 1-256.

- - 1957. Le genre Sphaerella Gray. Bull. Mus. Nat. Hist. Nat. Paris, Sér. 2, vol. 29, no. 6, pp. 493-495.

1958. Révision de la genres Sarcophytum et Lobophytum. Zool. Verh., no. 36, pp. 1-180.

Utinomi, H. 1950a. Some xeniid alcyonarians from Japan and adjacent localities. Publ. Seto Mar. Biol. Lab., vol. 1, no. 3, pp. 81-91.

1950b. Clavularia racemosa, new primitive alcyonarian found in Japan and Formosa. Annot. Zool. Japon., vol. 24, no. 1, pp. 38-44.

1951. Asterospicularia laurae, n. gen. et n. sp., the type of a new family of alcyonarians with stellate spicules. Pacific Sci., vol. 5, no. 2, pp. 190-196.

- 1953. Invertebrate fauna of the intertidal zone of the Tokara Islands. VI. Alcyonaria. Publ. Seto Mar. Biol. Lab., vol. 3, no. 2, pp. 149-160, pl. 8.

1954a. Some alcyoniid octocorals from Kii coast, middle Japan. Ibid,, vol. 4, no. 1, pp. $45-55$, pl. 1.

1954b. Some nephtheid octocorals from Kii coast, middle Japan. Ibid., vol. 4, no. 1, pp. 57-66, pl. 2.

1956. On some alcyonarians from the West-Pacific Islands (Palau, Ponape and Bonins). Ibid., vol. 5, no. 2 , pp. 221-242.

(* Not directly referred to.) 